\title{
Comparison of Meat Characteristics between Korean Native Duck and Imported Commercial Duck Raised under Identical Rearing and Feeding Condition
}

\author{
Muhlisin, Dong Soo Kim, Yeong Rae Song, Hong Rae Kim¹, Hyung Joo Kwon ${ }^{1}$, Byoung Ki An¹, \\ Chang Won Kang ${ }^{2}$, Hak Kyu Kim³ ${ }^{3}$, and Sung Ki Lee* \\ Department of Animal Products and Food Science, Kangwon National University, Chuncheon 200-701, Korea \\ ${ }^{1}$ College of Animal Bioscience and Technology, Konkuk University, Seoul 143-701, Korea \\ ${ }^{2}$ Department of Animal Science and Environment, Konkuk University, Seoul 143-701, Korea \\ ${ }^{3}$ Poultry Science Division, National Institute of Animal Science, RDA, Seonghwan 330-801, Korea
}

\begin{abstract}
This research was conducted to compare the meat characteristics of Korean native duck and imported commercial duck. The Korean native ducks and imported commercial ducks (broiler duck: Grimaud) were raised under identical rearing and feeding conditions for $8 \mathrm{wk}$ and $6 \mathrm{wk}$, respectively. At the end of the rearing period, ten ducks from each group were slaughtered, and breast and leg meat were obtained $24 \mathrm{~h}$ after slaughtering for analyses of meat characteristics. The results showed that the breast of Korean native ducks contained lower moisture and fat, and higher protein and water holding capacity (WHC) than those of imported commercial ducks $(p<0.05)$. The breast of Korean native ducks also had higher CIE a* and lower CIE L* $(p<0.05)$. After cooking, the breast meat of Korean native ducks had higher shear-force, sensory attributes of texture, taste and overall likeness $(p<0.05)$. Also, the breast meat of Korean native ducks contained a higher percentage of palmitic acid $\left(\mathrm{C}_{16: 0}\right)$ and arachidonic acid $\left(\mathrm{C}_{20: 4}\right)(p<0.05)$ than those of imported commercial ducks. Furthermore, the leg meat of Korean native ducks contained higher percentages of total unsaturated fatty acid and lower percentages of total saturated fatty acid $(p<0.05)$. It is concluded that the meat from Korean native ducks, especially breast meat, had better quality parameters and contained higher amounts of unsaturated fatty acids.
\end{abstract}

Key words: Korean native duck, imported commercial duck, meat characteristics, fatty acid composition

\section{Introduction}

Duck is becoming one of the most popular poultry commodities besides chicken in Asia, especially in East and Southeast Asian countries. Duck meats are well known for its unique flavor and taste, high composition of essential amino acids and high percentage of polyunsaturated fatty acids (Pingel, 2009). In Korea, duck meat is being serving in restaurant with various cooking methods, such as grilled, smoked, boiled (soup), etc. The demand of duck meat is increasing continuously because a variety of cooking methods and the number of consumers are increasing. Moreover, food companies are trying to develop products made of duck meat, such as ready-to-

\footnotetext{
*Corresponding author: Sung Ki Lee, Department of Animal Products and Food Science, Kangwon National University, Chuncheon 200-701, Korea. Tel: 82-33-250-8646, Fax: 82-33-251-7719, Email: skilee@kangwon.ac.kr
}

eat smoked duck, duck sausage, and so on. It is a big challenge for the poultry industry to meet the demand of duck meats.

About $65 \%$ of the world duck production was produced in China, while only $1.58 \%$ was produced in South Korea in 2007 (Pingel, 2009). The duck production in South Korea has increased continuously within a short period, and this increment resulted not only from the growing population of local breeds, but also from expanding imported commercial ducks from foreign breeding companies. Comparing with imported commercial ducks (included in the Grimoud duck group), Korean native ducks (Anas platyrhynchos) have colored-feathers and they grow relatively slowly with poor feed efficiency (Hong et al., 2012). Korean native ducks also have smaller average body weight $(2.6 \mathrm{~kg})$ and longer rearing period $(8 \mathrm{wk})$ than that of imported commercial ducks (3.0 kg; 6-7 wk) (Kim et al., 2012a). But, the Korean native ducks have unique meat flavor and texture (Kim et al., 2012a), and 
thus can be developed as an alternative, namely fastgrowing commercial breeds.

This study was conducted to compare the meat characteristics of two types of ducks, Korean native ducks and imported commercial ducks which were raised under the identical rearing and feeding condition.

\section{Material and Methods}

\section{Animals and management}

A total of one hundred-twenty 1-d old Korean native ducklings and imported commercial ducklings (broiler duck: Grimaud) were randomly placed into three replicate pens. Twenty ducklings per each pen were raised for $8 \mathrm{wk}$ (Korean native ducks) or $6 \mathrm{wk}$ (imported commercial ducks). They were fed the same standard diets: starter ( $23 \% \mathrm{CP}, 3,000 \mathrm{kcal} / \mathrm{kg}$ of ME), from 1-d to $3 \mathrm{wk}$; grower ( $21 \% \mathrm{CP}, 3,100 \mathrm{kcal} / \mathrm{kg}$ of ME), from $3 \mathrm{wk}$ until the end of the experimental period. The experimental diets were formulated to meet or exceed the nutrient requirements of National Research Council (1994) as shown in Table 1. The ducks were set free of access to the diets and water. All animal care procedures were approved by Institutional Animal Care and Use Committee in Konkuk University.

At the end of the experimental period, ten ducks per each group were selected and weighed individually. Mean live body weights of ten ducks selected from each group

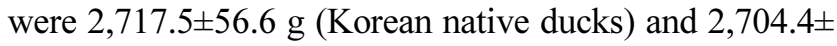
$75.2 \mathrm{~g}$ (imported commercial ducks), respectively. They were slaughtered by neck cut, scalded with hot water $\left(60^{\circ} \mathrm{C}\right.$ for $\left.2 \mathrm{~min}\right)$, and removed the feathers mechanically. The dressing percentage of Korean native ducks and imported commercial ducks were $65.9 \pm 4.4 \mathrm{~g}$ and $63.3 \pm 2.5$ g, respectively. Carcasses were eviscerated manually and portioned into commercial cuts such as neck, breast, leg, wing and back. The breast and leg were chilled for 30 min in ice water and transferred to cold room at $5^{\circ} \mathrm{C}$ for $24 \mathrm{~h}$ and then prepared separately for further analyses.

\section{Proximate and $\mathrm{pH}$ measurements}

The proximate analyses including moisture, crude protein, crude fat and ash were performed using Association of Official Analytical Chemists methods (AOAC, 2007). For $\mathrm{pH}$ measurement, $10 \mathrm{~g}$ of sample was homogenized at 10,000 rpm for $60 \mathrm{~s}$ using a homogenizer (PH91, SMT Co. Ltd., Japan) with $100 \mathrm{~mL}$ of distilled water. The $\mathrm{pH}$ of meat slurry at room temperature was measured using a $\mathrm{pH}$ meter (SevenEasy pH, Mettler-Toledo GmbH, Switzerland).
Table 1. Feed formula and chemical composition of basal diets

\begin{tabular}{lrr}
\hline \hline \multicolumn{1}{c}{ Items } & Starter & Grower \\
\hline Yellow corn & 40.41 & 50.88 \\
Wheat & 12.00 & 12.00 \\
Corn gluten meal & 6.50 & 4.56 \\
Soybean meal & 25.65 & 17.17 \\
Canola meal & 4.46 & 6.04 \\
Wheat bran & 3.00 & 2.52 \\
Soybean oil & 3.84 & 3.00 \\
Salt & 0.30 & 0.30 \\
L-Lysine HCl (78\%) & 0.17 & 0.10 \\
Choline-Cl (50\%) & 0.01 & 0.01 \\
Dicalcium phosphate & 1.72 & 1.37 \\
DL-Methionine (98\%) & 0.17 & 0.03 \\
Limestone & 1.02 & 1.27 \\
Vitamin mix ${ }^{1)}$ & 0.10 & 0.10 \\
Mineral mix ${ }^{2)}$ & 0.15 & 0.15 \\
Pellet binder & 0.50 & 0.50 \\
Total & 100.00 & 100.00 \\
CP, \% & 23.00 & 19.00 \\
Ca, \% & 0.90 & 0.90 \\
Avail. P, \% & 0.42 & 0.35 \\
Total Lys., \% & 1.21 & 0.94 \\
Total TSAA, \% & 1.00 & 0.75 \\
Limestone & 1.00 & 1.00 \\
MEn, kcal/kg & $3,000.00$ & $3,100.00$ \\
\hline
\end{tabular}

${ }^{1)}$ Vitamin mixture provided following nutrients per $\mathrm{kg}$ of diet: vitamin $\mathrm{A}, 10,000 \mathrm{IU}$; vitamin $\mathrm{D}_{3}$, 2,300 IU; vitamin $\mathrm{E}, 20 \mathrm{IU}$; vitamin $\mathrm{K}_{3}, 2 \mathrm{mg}$; vitamin $\mathrm{B}_{1}, 2 \mathrm{mg}$; vitamin $\mathrm{B}_{2}, 5 \mathrm{mg}$; vitamin $\mathrm{B}_{6}, 3.5 \mathrm{mg}$; vitamin $\mathrm{B}_{12}, 0.02 \mathrm{mg}$; biotin, $0.12 \mathrm{mg}$; niacin, 30 $\mathrm{mg}$; pantothenic acid, $10 \mathrm{mg}$; folic acid, $0.7 \mathrm{mg}$

${ }^{2)}$ Mineral mixture provided following nutrients per $\mathrm{kg}$ of diet: $\mathrm{Fe}$, 70 mg; Zn, 60 mg; Mn, 8 mg; Cu, 7.5 mg; I, 1 mg; Se, 0.2 mg; Co, $0.13 \mathrm{mg}$

\section{Instrumental color}

The instrumental color of fresh breast and leg meat, and cooked breast meat, including lightness $\left(\mathrm{L}^{*}\right)$, redness $\left(a^{*}\right)$, and yellowness $\left(b^{*}\right)$ were measured using a color difference meter (CR-400, Konica Minolta Sensing Inc., Japan). For cooked breast meat instrumental color determination, $100 \mathrm{~g}$ of breast meat was boiled individually in polyethylene bags immersed in an $80^{\circ} \mathrm{C}$ water bath for 30 min. The samples were cooled for $30 \mathrm{~min}$ and ten times random measurements were taken from each sample. The color instrument was standardized with a white plate (Illuminant $\mathrm{C}$ : $\mathrm{Y}=93.6, \mathrm{x}=0.3134$, and $\mathrm{y}=0.3194$ ).

\section{Water holding capacity (WHC), cooking loss and shear-force}

The water holding capacity (WHC) was performed according to filter paper pressed method (Grau and Hamm, 1953). Briefly, $0.3 \mathrm{~g}$ of breast or leg meat was weighed 
on a Whatman filter paper (No. 2). The samples were pressed between 2 plexiglass plates for $5 \mathrm{~min}$. The areas of pressed sample and water were measured using a planimeter (Super Planix $\alpha$, Tamaya Technics Inc., Japan). The WHC was calculated as follows:

WHC $(\%)=($ area of sample/area of water $) \times 100 \%$.

To determine the cooking loss, $100 \mathrm{~g}$ of breast meat or $50 \mathrm{~g}$ of leg meat of each sample was boiled individually in polyethylene bags immersed in an $80^{\circ} \mathrm{C}$ water bath for $30 \mathrm{~min}$. The samples were cooled for $30 \mathrm{~min}$. The initial weights of uncooked and cooked meat were recorded, and the cooking loss was calculated as follows:

$$
\begin{aligned}
\text { Cooking loss }(\%)=[(\text { uncooked weight-cooked weight }) / \\
\text { uncooked weight }] \times 100 \%
\end{aligned}
$$

After determining the cooking loss, cooked breast meat then were cut into cubes $(1.0 \times 1.0 \times 1.0 \mathrm{~cm})$ and the measurements of shear-force was performed using texture analyzer (TA-XT2 $i$ version 6.06, Stable Micro Systems Ltd., UK). The instrument settings were: maximum cell load: $30 \mathrm{~kg}$; probe pre-test speed: $1 \mathrm{~mm} / \mathrm{s}$; test speed: $1 \mathrm{~mm} /$ $\mathrm{s}$; post-test speed: $5 \mathrm{~mm} / \mathrm{s}$; and cutting distance: $100 \%$. Twelve measurements were performed on each sample and the shear-force values were expressed on kgf.

\section{Sensory evaluations}

A sensory panel was asked to evaluate the cooked Korean native ducks and imported commercial ducks. The breast meats were cooked on a polyethylene bags immersed in an $80^{\circ} \mathrm{C}$ water bath for $30 \mathrm{~min}$. After cooling for $30 \mathrm{~min}$, the sample was cut into a $1 \times 1 \times 1 \mathrm{~cm}$ cubes. A panel consisting of 20 people was assigned to score the consumer preference test including color appearance, taste, smell, texture and overall likeness. The preference scores were 9-point hedonic scale, where 1 was "very bad", 3 was "bad", 5 was "normal", 7 was "good", and 9 was "very good".

\section{Fatty acid composition}

The lipids of breast meat and leg meat were extracted using the methods described by Folch et al. (1957). Briefly, $5.0 \mathrm{~g}$ of sample was homogenized with $25 \mathrm{~mL}$ of chloroform:methanol $(2: 1, \mathrm{v} / \mathrm{v})$ at $13,500 \mathrm{rpm}$ using a homogenizer (Ultra Turax T25 basic, Ika Werke Gmbh \& Co., Germany). The homogenates were added with $0.88 \%$ of $\mathrm{KCl}$ and then were centrifuged at 3,000 rpm for 10 min. The supernatant was evaporated at $38^{\circ} \mathrm{C}$ on an $\mathrm{N}_{2}$ gas blow concentrator (MG 2200, Eyela Co., Japan). The methylation was performed according to AOAC (2007). The fatty acid composition was analyzed in Agilent 6890 $\mathrm{N}$ (Agilent Technologies, USA) equipped with automatic sampler Agilent 7683 (Agilent Technologies, USA) using an HP-Innowax ( $30 \mathrm{~m}$ length $\times 0.32 \mathrm{~mm}$ i.d. $\times 0.25 \mu \mathrm{m}$ film thickness; Agilent Technologies, USA). One micro liter of sample was injected (split $1: 10 ; 260^{\circ} \mathrm{C}$ ) and then was carried out at a flow rate of $1.0 \mathrm{~mL} / \mathrm{min}$ using helium. The oven temperature was set at $150^{\circ} \mathrm{C}$ for $1 \mathrm{~min}, 150$ $200^{\circ} \mathrm{C}$ at $15^{\circ} \mathrm{C} / \mathrm{min}, 200-250^{\circ} \mathrm{C}$ at $3^{\circ} \mathrm{C} / \mathrm{min}$, and $250^{\circ} \mathrm{C}$ for $5 \mathrm{~min}$. The detector (FID) was set at $280^{\circ} \mathrm{C}$.

\section{Statistical analysis}

The data were analyzed using SPSS statistic 19.0 for Windows Evaluation Version (2010). Analysis of variance (ANOVA) followed by Duncan's multiple range tests was used to determine statistical significance among the mean at $95 \%$ significance level of proximate, $\mathrm{pH}$, instrumental color, WHC, cooking loss and fatty acid composition. Student t-test was used to determine the significance differences between mean at 95\% significance level of shear-force, instrumental color and sensory evaluation of cooked duck breast meat.

\section{Results and Discussion}

\section{Proximate analysis and $\mathrm{pH}$}

The chemical compositions in breast and leg meat of Korean native ducks and imported commercial ducks are shown in Table 2. Breast meat of Korean native ducks had significantly higher protein and lower fat and moisture content $(p<0.05)$ than that of imported commercial ducks. Comparing within duck parts, breast meat also had significantly higher protein content $(p<0.05)$ than leg meat. These results showed that Korean native ducks, especially breast meat has an attractive nutritional composition to consumers who are concerned about health. Ali et al. (2007) reported that breast meat of Cherry berry ducks had $20.06 \%$ of protein content, which was significantly lower than chicken breast meat $(22.04 \%)$. It is noted that the low fat content in Korean native ducks only can be observed in breast meat. The fat content in leg meat of Korean native ducks was the highest among the data $(p<0.05)$. Our research had similar chemical composition to Ali et al. (2007), but the protein content of Korean native ducks was similar to that of chicken breast meat $(21.90 \%$ vs $22.04 \%)$. Fat content in breast and leg meat of Korean native ducks was lower than that of Spanish wild duck (Anas platyrhynchos). Cobos et al. (2000) 
Table 2. Proximate analysis (\%), pH, water holding capacity (WHC; \%), cooking loss (\%), and instrumental color of breast and leg meat of Korean native ducks and imported commercial ducks raised under identical rearing and feeding condition

\begin{tabular}{|c|c|c|c|c|}
\hline \multirow{2}{*}{ Parameters } & \multicolumn{2}{|c|}{ Korean native ducks } & \multicolumn{2}{|c|}{ Imported commercial ducks } \\
\hline & Breast & Leg & Breast & Leg \\
\hline \multicolumn{5}{|l|}{ Proximate } \\
\hline Moisture & $75.77 \pm 0.35^{\mathrm{c}}$ & $76.35 \pm 0.73^{\mathrm{b}}$ & $76.91 \pm 0.39^{\mathrm{b}}$ & $77.11 \pm 0.45^{\mathrm{a}}$ \\
\hline Ash & $1.10 \pm 0.22^{\mathrm{a}}$ & $0.89 \pm 0.10^{\mathrm{b}}$ & $1.12 \pm 0.08^{\mathrm{a}}$ & $0.93 \pm 0.10^{\mathrm{b}}$ \\
\hline Protein & $21.84 \pm 0.92^{\mathrm{a}}$ & $19.36 \pm 1.10^{\mathrm{b}}$ & $20.19 \pm 1.16^{\mathrm{b}}$ & $19.29 \pm 1.13^{b}$ \\
\hline Fat & $1.30 \pm 0.17^{\mathrm{d}}$ & $3.40 \pm 1.83^{\mathrm{a}}$ & $1.79 \pm 0.53^{\mathrm{c}}$ & $2.67 \pm 1.43^{b}$ \\
\hline $\mathrm{pH}$ & $5.67 \pm 0.02^{\mathrm{c}}$ & $6.75 \pm 0.09^{\mathrm{a}}$ & $5.73 \pm 0.06^{\mathrm{c}}$ & $6.63 \pm 0.12^{\mathrm{b}}$ \\
\hline WHC & $48.17 \pm 4.42^{\mathrm{b}}$ & $59.58 \pm 10.55^{\mathrm{a}}$ & $36.54 \pm 2.99^{\mathrm{c}}$ & $65.90 \pm 9.85^{\mathrm{a}}$ \\
\hline Cooking loss & $31.52 \pm 1.35^{\mathrm{a}}$ & $32.21 \pm 4.57^{\mathrm{a}}$ & $31.80 \pm 2.12^{\mathrm{a}}$ & $28.73 \pm 4.33^{\mathrm{a}}$ \\
\hline \multicolumn{5}{|c|}{ Instrumental color } \\
\hline CIE L* & $44.90 \pm 1.90^{\mathrm{c}}$ & $48.29 \pm 2.26^{\mathrm{b}}$ & $49.53 \pm 1.95^{\mathrm{a}}$ & $47.93 \pm 2.79^{b}$ \\
\hline CIE a* & $14.40 \pm 1.35^{\mathrm{b}}$ & $15.55 \pm 2.49^{\mathrm{a}}$ & $13.50 \pm 1.53^{\mathrm{c}}$ & $13.53 \pm 1.44^{\mathrm{c}}$ \\
\hline CIE b* & $6.86 \pm 0.91^{\mathrm{c}}$ & $9.15 \pm 1.88^{\mathrm{a}}$ & $8.25 \pm 1.22^{\mathrm{b}}$ & $7.33 \pm 1.56^{\mathrm{c}}$ \\
\hline
\end{tabular}

Data are presented as Means $\pm \mathrm{SD}$ (Standard deviation, $\mathrm{n}=12$ )

${ }^{\text {a-d }}$ Values within each row with different superscripts are significantly different $(p<0.05)$.

reported that breast meat of Spanish wild ducks had $3.39 \%$ of fat content and leg meat of the same breed had $3.84 \%$. As customers are concerned more about their health related with fat intake, they seem to believe that the breast meats of Korean native ducks are good for health.

$\mathrm{pH}$ had no significant difference between breast meat of Korean native ducks and imported commercial ducks (5.67 and 5.73, respectively). $\mathrm{pH}$ values of Korean native ducks and imported commercial ducks were similar to breast meat of Pekin ducks (Kim et al., 2012b) and broiler chickens (Wattanachant et al., 2004), but were lower than that of any other duck breeds. For example, Mazanowski et al. (2003) reported that $\mathrm{pH}$ of A44 and A55 strains of ducks were 6.0 and 6.4 , respectively. $\mathrm{pH}$ value might be various depending on the breeds, feeds, and postmortem condition. Alvarado and Sams (2000) reported that $\mathrm{pH}$ of breast meat of White Pekin ducks decreased as postmortem time increased. Significantly different $\mathrm{pH}$ was observed depending on parts of meat. Namely, the $\mathrm{pH}$ of leg meat was higher than that of breast meat in both Korean native ducks and imported commercial ducks $(p<0.05)$. It was also observed that leg meat of Korean native ducks had higher $\mathrm{pH}$ than that of imported commercial ducks $(p<$ 0.05). According to Lyon et al. (1984) and Wang et al. (2009), breast meat of broiler chickens had lower $\mathrm{pH}$ than that of leg meat.

\section{Water holding capacity and cooking loss}

WHC and cooking loss were observed as shown in Table 2. WHC of Korean native ducks (48.17\%) was higher than that of imported commercial ducks (36.54\%).
Kim et al. (2012b) also reported that Pekin ducks had similar WHC (45.43\%) to breast meat of Korean native ducks. Leg meat of both duck breeds had higher WHC than breast meat $(p<0.05)$. No significant difference was observed in cooking loss between Korean native ducks and imported commercial ducks (31.80 and 31.52\%). For reference, breast meat of Cherry berry ducks had $34.48 \%$ of cooking loss (Ali et al., 2007), and White Pekin ducks deboned after $0.25 \mathrm{~h}$ had $31.26 \%$ of cooking loss (Alvarado and Sams, 2000). Alvarado and Sams (2000) also stated that cooking loss of duck meat varied according to different deboning time. There was no statistical difference of cooking loss between breast and leg meat in both Korean native ducks and imported commercial ducks. These results were different from the research done by Wattanachant et al. (2004), in which breast meat had higher cooking loss than leg meat in broiler chickens, but lower cooking loss in Thai Indigenous chickens.

\section{Instrumental color of fresh meat}

Color is one of the most important quality parameters, and especially red color of fresh meat is the most affected consumers' purchasing (Mancini and Hunt, 2005). The instrumental color evaluation of fresh meat (Table 2) showed that the Korean native ducks had significantly higher redness (CIE a*) in both breast and leg meat than that of imported commercial ducks $(\mathrm{p}<0.05)$, but it had lower lightness (CIE L*) and yellowness (CIE b*) in breast meat than that of imported commercial ducks $(p<0.05)$. Comparing with results of other study, the redness of breast meat of Korean native ducks (14.40) was lower 
than that of Cherry berry ducks (15.50) (Ali et al., 2007) and Pekin ducks (15.61) (Kim et al., 2012b). It was reported that duck breast meat had higher redness than broiler breast meat (Ali et al., 2007; Wattanachant, 2004). The leg meat of Korean native ducks had higher redness than the breast meat, and showed the highest value among the 4 parts of treatments $(p<0.05)$. A similar result was reported that leg meat had higher CIE a* than breast meat in broiler and Thai indigenous chickens (Wattanachant et al., 2004).

\section{Shear-force, instrumental color and sensory evalu- ation of cooked breast meat}

Shear-force, instrumental color and sensory evaluation scores of cooked duck breast meat were observed as shown in Table 3. It is known that ducks meat had unique texture compared to other poultry meat (Pingel, 2009). The shear-force of Korean native ducks $\left(3.81 \mathrm{~kg} / \mathrm{cm}^{3}\right)$ was significantly higher $(p<0.05)$ than that of imported commercial duck $\left(2.73 \mathrm{~kg} / \mathrm{cm}^{3}\right)$. Shear-force of Korean native ducks was similar to that of Chungdongori (Anas platyrhynchos) (Ali et al., 2008) and Pekin ducks (Kim et al., 2012b), in which the shear-forces were 3.76 and 4.18 $\mathrm{kg} / \mathrm{cm}^{3}$ respectively. The higher shear-force measured from Korean native ducks than imported commercial ducks might be related with genetic characteristics of the breed and the different slaughter age. It was reported that Korean native ducks grow relatively slowly with poor feed efficiency (Hong et al., 2012) and have unique meat texture (Kim et al., 2012a). And, on our study, the slaugh-

Table 3. The shear-force $\left(\mathrm{kg} / \mathrm{cm}^{3}\right)$, instrumental color, and sensory evaluation of cooked breast meat of Korean native ducks and imported commercial ducks raised under identical rearing and feeding condition

\begin{tabular}{lcc}
\hline \hline \multicolumn{1}{c}{ Parameters } & Korean native ducks & $\begin{array}{c}\text { Imported } \\
\text { commercial ducks }\end{array}$ \\
\hline Shear-force & $3.81 \pm 1.49^{\mathrm{a}}$ & $2.73 \pm 1.22^{\mathrm{b}}$ \\
\hline Instrumental color & & \\
CIE L* $^{*}$ & $58.22 \pm 1.68^{\mathrm{b}}$ & $65.30 \pm 1.59^{\mathrm{a}}$ \\
$\mathrm{CIEa}^{*}$ & $6.65 \pm 0.48^{\mathrm{a}}$ & $6.87 \pm 0.94^{\mathrm{a}}$ \\
$\mathrm{CIE} \mathrm{b}^{*}$ & $10.92 \pm 0.67^{\mathrm{b}}$ & $12.12 \pm 0.70^{\mathrm{a}}$ \\
\hline Sensory evaluation & & \\
Color & $6.4 \pm 2.2^{\mathrm{a}}$ & $6.2 \pm 1.2^{\mathrm{a}}$ \\
Taste & $7.4 \pm 1.5^{\mathrm{a}}$ & $6.0 \pm 0.9^{\mathrm{b}}$ \\
Smell & $6.4 \pm 0.8^{\mathrm{a}}$ & $5.8 \pm 1.2^{\mathrm{a}}$ \\
Texture & $7.2 \pm 1.5^{\mathrm{a}}$ & $5.8 \pm 1.7^{\mathrm{b}}$ \\
Overall likeness & $7.6 \pm 1.4^{\mathrm{a}}$ & $6.4 \pm 1.3^{\mathrm{b}}$ \\
\hline
\end{tabular}

Data are presented as Means \pm SD (Standard deviation)

${ }^{\mathrm{a}, \mathrm{b}}$ Values within each row with different superscripts are significantly different $(p<0.05)$. ter age of Korean native ducks (8 wk) was older than commercial native ducks (6 wk). Lyon and Hamm (1984) and Abdullah et al. (2010) stated that hardness of broiler breast meat increased with the increment of age. The result of instrumental shear-force was similar with the texture scores from the sensory evaluation (Table 3 ). The panels scored $7.2 \pm 1.5$ in the texture of cooked breast meat of Korean native ducks, and it was significantly higher than the score of imported commercial ducks (5.8 11.7$)$.

For instrument color, cooked duck breast had no difference in redness between Korean native ducks and imported commercial ducks $(p>0.05)$, but lightness and yellowness of cooked breast of Korean native ducks were lower than that of imported commercial ducks $(p<0.05)$. Even though a significance higher redness was found in fresh meat of Korean native ducks, there was no statistical difference of redness in cooked breast meat between two different duck breeds. Moreover, cooked breast Korean native ducks had a greater decrease of redness than imported commercial ducks, as the results the redness of Korean native ducks was numerically lower than that of imported commercial ducks (6.65 \pm 0.48 and $6.87 \pm 0.94$, respectively). It is assumed that the greater decrease of redness after cooking in breast meat of Korean native ducks might be attributed to the greater pigments' denaturation caused by specific biochemical condition. Holownia et al. (2003) stated that biochemical conditions such as $\mathrm{pH}$, redox potential, reacting ligands of the meat are related to structure and reactivity of the pigment in cooked meat. Additionally, preslaughter factors such as genetic, age and sex also played role in color and myoglobin concentration in poultry meat (Froning et al., 1968).

According to the sensory evaluated by the panels, average scores for the taste attributes of cooked breast of Korean native ducks was significantly higher than that of imported commercial ducks ( $7.14 \pm 1.5$ and 6.0 0.9$)(p<$ $0.05)$. Moreover, the average score of overall likeness of Korean native ducks also was significantly higher than that of imported commercial ducks $(p<0.05)$. Therefore, the sensory quality of cooked breast meat of Korean native ducks was better than that of imported commercial ducks.

\section{Fatty acid composition}

The fatty acid composition of breast and leg meat of Korean native ducks and imported commercial ducks are shown in Table 4. The major fatty acid composition in both breeds was oleic acid $\left(\mathrm{C}_{18: 1} ; 32.66-41.10 \%\right)$, linoleic acid $\left(\mathrm{C}_{18: 2} ; 24.40-27.44 \%\right)$, and palmitic acid $\left(\mathrm{C}_{16: 0}\right.$; 
Table 4. Fatty acid composition (\%) of Korean native ducks and imported commercial ducks raised under identical rearing and feeding condition

\begin{tabular}{|c|c|c|c|c|}
\hline \multirow{2}{*}{ Fatty acid } & \multicolumn{2}{|c|}{ Korean native ducks } & \multicolumn{2}{|c|}{ Imported commercial ducks } \\
\hline & Breast & Leg & Breast & Leg \\
\hline Mystiric acid $\left(\mathrm{C}_{14: 0}\right)$ & $0.57 \pm 0.05^{\mathrm{a}}$ & $0.55 \pm 0.04^{\mathrm{a}}$ & $0.55 \pm 0.04^{\mathrm{a}}$ & $0.61 \pm 0.03^{\mathrm{a}}$ \\
\hline Palmitic acid $\left(\mathrm{C}_{16: 0}\right)$ & $24.12 \pm 1.02^{\mathrm{a}}$ & $21.35 \pm 0.66^{\mathrm{c}}$ & $23.09 \pm 0.23^{\mathrm{b}}$ & $21.52 \pm 0.55^{\mathrm{c}}$ \\
\hline Stearic acid $\left(\mathrm{C}_{18: 0}\right)$ & $10.08 \pm 1.33^{\mathrm{a}}$ & $6.70 \pm 0.59^{\mathrm{c}}$ & $10.34 \pm 1.22^{\mathrm{a}}$ & $8.25 \pm 0.55^{\mathrm{b}}$ \\
\hline Oleic acid $\left(\mathrm{C}_{18: 1}\right)$ & $32.66 \pm 3.39^{\mathrm{b}}$ & $41.10 \pm 1.68^{\mathrm{a}}$ & $34.64 \pm 4.39^{\mathrm{b}}$ & $38.69 \pm 2.01^{\mathrm{a}}$ \\
\hline Linoleic acid $\left(\mathrm{C}_{18: 2}\right)$ & $24.40 \pm 1.08^{\mathrm{b}}$ & $27.44 \pm 0.64^{\mathrm{a}}$ & $25.20 \pm 1.41^{\mathrm{b}}$ & $27.40 \pm 2.29^{\mathrm{a}}$ \\
\hline Linolenic acid $\left(\mathrm{C}_{18: 3}\right)$ & $0.08 \pm 0.02^{\mathrm{a}}$ & $0.08 \pm 0.01^{\mathrm{a}}$ & $0.07 \pm 0.03^{\mathrm{a}}$ & $0.08 \pm 0.01^{\mathrm{a}}$ \\
\hline Cis-eicosenic acid $\left(\mathrm{C}_{20: 1}\right)$ & $0.46 \pm 0.06^{\mathrm{b}}$ & $0.56 \pm 0.05^{\mathrm{a}}$ & $0.53 \pm 0.07^{\mathrm{a}}$ & $0.53 \pm 0.01^{\mathrm{a}}$ \\
\hline Arachidonic acid $\left(\mathrm{C}_{20: 4}\right)$ & $7.50 \pm 2.10^{\mathrm{a}}$ & $2.11 \pm 0.70^{\mathrm{c}}$ & $5.44 \pm 1.88^{\mathrm{b}}$ & $2.80 \pm 0.78^{\mathrm{c}}$ \\
\hline Eicosepentaenoic acid $\left(\mathrm{C}_{20: 5}\right)$ & $0.11 \pm 0.03^{\mathrm{a}}$ & $0.10 \pm 0.02^{\mathrm{a}}$ & $0.13 \pm 0.02^{\mathrm{a}}$ & $0.12 \pm 0.01^{\mathrm{a}}$ \\
\hline$\Sigma$ SFA & $34.78 \pm 2.31^{\mathrm{a}}$ & $28.60 \pm 1.05^{\mathrm{c}}$ & $33.99 \pm 1.32^{\mathrm{a}}$ & $30.38 \pm 0.44^{b}$ \\
\hline$\Sigma U F A$ & $65.21 \pm 2.30^{\mathrm{c}}$ & $71.40 \pm 1.05^{\mathrm{a}}$ & $66.00 \pm 1.32^{\mathrm{c}}$ & $69.61 \pm 0.44^{\mathrm{b}}$ \\
\hline$\Sigma$ MUFA & $33.11 \pm 3.44^{\mathrm{b}}$ & $41.67 \pm 1.70^{\mathrm{a}}$ & $35.17 \pm 4.43^{b}$ & $39.22 \pm 2.01^{\mathrm{a}}$ \\
\hline$\Sigma$ PUFA & $32.10 \pm 1.41^{\mathrm{a}}$ & $29.73 \pm 0.94^{b}$ & $30.84 \pm 1.17^{\mathrm{b}}$ & $30.40 \pm 1.76^{\mathrm{b}}$ \\
\hline$\Sigma \mathrm{n}-6$ & $31.91 \pm 1.38^{\mathrm{a}}$ & $29.55 \pm 0.93^{\mathrm{b}}$ & $30.64 \pm 1.14^{\mathrm{b}}$ & $30.20 \pm 1.76^{b}$ \\
\hline$\Sigma \mathrm{n}-3$ & $0.19 \pm 0.03^{\mathrm{a}}$ & $0.17 \pm 0.02^{\mathrm{a}}$ & $0.20 \pm 0.03^{\mathrm{a}}$ & $0.19 \pm 0.02^{\mathrm{a}}$ \\
\hline
\end{tabular}

Data are presented as Means \pm SD (Standard deviation, $n=12$ )

${ }^{\mathrm{a}-\mathrm{d}}$ Values within each row with different superscripts are significantly different $(p<0.05)$.

21.35-24.12\%). The percentage of other fatty acids such as stearic acid $\left(\mathrm{C}_{18: 0}\right)$ and arachidonic acid $\left(\mathrm{C}_{20: 4}\right)$ were $6.70-10.34 \%$ and $2.11-7.50 \%$ respectively, and the rest fatty acids were below $1 \%$. Breast meat of Korean native ducks had more percentage of palmitic acid and arachidonic acid, total PUFA and total n- 6 fatty acids than those of imported commercial ducks $(p<0.05)$. Similar to this result, Cobos et al. (2000) reported that the major fatty acids in breast meat of Spanish wild ducks were $\mathrm{C}_{16: 0}$, $\mathrm{C}_{18: 0}, \mathrm{C}_{18: 1}, \mathrm{C}_{18: 2}$ and $\mathrm{C}_{20: 4}$.

The fatty acid composition of duck breast and leg meat is showing the characteristics of each. The leg meat of both Korean native ducks and imported commercial ducks contained higher percentage of oleic and linoleic acid, but contained lower percentage of palmitic acid, stearic acid and arachidonic acid than breast meat. Cobos et al. (2000) reported that leg meat of Spanish wild ducks had lower arachidonic acid than breast meat of the same breed. According to Wang et al. (2009), leg meat of Cherry berry ducks had $25 \%$ of arachidonic acid among total fatty acids. On the other hand, leg meat of Korean native ducks and imported commercial ducks showed lower level of arachidonic acid (2.11 and 2.80\%, respectively). Leg meat also contained higher percentage of total unsaturated fatty acids, especially total monounsaturated fatty acid (MUFA) than breast meat, and lower percentage of saturated fatty acids than breast meat regardless of two breeds. In case of chicken meat, Wattanachant et al. (2004) reported that the percentage of fatty acid composi- tion of leg meat and breast meat of broiler chickens were similar statistically.

\section{Acknowledgements}

This study was supported by a grant of Rural Development Administration.

\section{References}

1. Abdullah, A. Y., Muwalla, M. M., Maharmer, H. O., Matarneh, S. K., and Ishmais, M. A. A. (2010) Effect of strain on performance, and age at slaughter and duration of post-chilling aging meat quality traits of broiler. Asian-Aust. J. Anim. Sci. 23, 1645-1656.

2. Ali, M. S., Kang, G. H., Yang, H. S., Jeong, J. Y., Hwang, Y. H., Park, G. B., and Joo, S. T. (2007) A comparison of meat characteristics between duck and chicken breast. Asian-Aust. J. Anim. Sci. 20, 1002-1006.

3. Ali, M. S., Yang, H. S., Jeong, J. Y., Moon, S. H., Hwang, Y. H., Park, G. B., and Joo, S. T. (2008) Effect of chilling temperature of carcass on breast meat quality of duck. Poultry Sci. 87, 1860-1867.

4. Alvarado, C. Z. and Sams, A. R. (2000) The influence of postmortem electrical stimulation on rigor mortis development, calpastatin activity, and tenderness in broiler and duck pectoralis. Poultry Sci.79, 1364-1368.

5. AOAC (2007) Official Methods of Analysis. 18th ed, Association of Official Analytical Chemists, Washington, DC.

6. Cobos, A., Veiga, A., and Diaz, O. (2000) Chemical and fatty acid composition of meat and liver of wild ducks (Anasplatyrhynchos). Food Chem. 68, 77-79. 
7. Folch, J., Lee, M., and Sloan-Stanley, G. H. (1957) A simple method for the isolation and purification of total lipids from animal tissues. J. Biol. Chem. 226, 497-509.

8. Froning, G. W., Daddario, J., and Hartung, T. E. (1968) Color and myoglobin concentration in turkey meat as affected by age, sex and strain. Poultry Sci. 47, 1827-1835.

9. Grau, R. and Hamm, R. A. (1953) A simple method for the determination of water binding in muscles. Naturwissenschaften 40, 29-30.

10. Holownia, K., Chinnan, M. S., and Reynolds, A. E. (2003) Pink color defect in poultry white meat as affected by endogenous conditions. J. Food Sci. 68, 742-747.

11. Hong, E. C., Choo, H. J., Kang, B. S., Kim, C. D., Heo, K. N., Lee, M. J., Hwangbo, J., Suh, O. S., Choi, H. C., and Kim, H. K. (2012) Performance of growing period of large-type Korean native duck. Korean J. Poult. Sci. 39, 143-149.

12. Kim, H. K., Kang, B. S., Hwangbo, J., Kim. C. D., Heo, K. N., Choo, H. J., Park, D. S., Suh O. S., and Hong E. C. (2012a) The study on grow performance and carcass yield of meattype Korean native ducks. Korean J. Poult. Sci. 39, 45-52.

13. Kim, H. W., Lee, S. H., Choi, J. H., Choi, Y. S., Kim, H. Y., Hwang, K. E., Park, J. H., Song, D. H., and Kim, C. J. (2012b) Effect of rigor state, thawing temperature, and processing on the physicochemical properties of frozen duck breast muscle. Poultry Sci. 91, 2662-2667.

14. Lyon, C. E. and Hamm, D. (1984) Effects of age and sex on the texture profile of hot stripped broiler breast meat. Poultry
Sci. 63, 2508-2510.

15. Lyon, C. E., Hamm, D., Thomson, J. E., and Hudspeth, J. P. (1984) The effect of holding time and added salt on $\mathrm{pH}$ and functional properties of chicken meat. Poultry Sci. 63, 19521957.

16. Mancini, R. A. and Hunt, M. C. (2005) Current research in meat color: review. Meat Sci. 71, 100-121.

17. Mazanowski, A., Kisiel T., and Gornowicz, E. (2003). Carcass quality, meat traits and chemical composition of meat in ducks of paternal strains A44 and A55. Animal Science Papers and Reports, Institute of Genetics and Animal Breeding, Poland, 21, 251-263.

18. National Research Council (1994) Nutrients Requirements of Poultry. $9^{\text {th }}$ ed. National Academic Press, Washington, DC.

19. Pingel, H. (2009) Waterfowl production for food security. Proceed. IV World Waterfowl Conference, Thrissur, India, pp. 5-15.

20. Wang, D.Y., Zhu, Y. Z., and Xu, W. M. (2009) Composition of intramuscular phospholipids and free fatty acids in three kinds of traditional Chinese duck meat products. Poultry Sci. 88, 221-226.

21. Wattanachant, S., Benjakul, S., and Ledward, D. A. (2004) Composition, color, and texture of Thai indigenous and broiler chicken muscles. Poultry Sci. 83, 123-128.

(Received 2012.10.15/Revised 2013.1.25/Accepted 2013.2.19) 